\title{
潜在キャラクタモデルによる聞き手のふるまいに 基づく対話エンゲージメントの推定
}

\section{Engagement Recognition from Listener's Behaviors in Spoken Dialogue Using a Latent Character Model}

\author{
井上 昂治 \\ 京都大学 大学院情報学研究科 \\ Koji Inoue \\ Graduate School of Informatics, Kyoto University \\ inouedsap.ist.i.kyoto-u.ac.jp \\ Divesh Lala \\ (同上) \\ lalaesap.ist.i.kyoto-u.ac.jp \\ 吉井 和佳
Kazuyoshi Yoshii \\ （同上） \\ yoshiiesap.ist.i.kyoto-u.ac.jp \\ 高梨 克也 \\ （同上） \\ takanasiesap.ist.i.kyoto-u.ac.jp \\ 河原達也 \\ （同上） \\ kawaharaesap.ist.i.kyoto-u.ac.jp
}

keywords: dialogue, engagement, behavior, character, latent model

\section{Summary}

This article addresses the estimation of engagement level based on the listener's behaviors such as backchannel, laughing, head nodding, and eye-gaze. Engagement is defined as the level of how much a user is being interested in and willing to continue the current interaction. When the engagement level is evaluated by multiple annotators, the criteria for annotating the engagement level would depend on each annotator. We assume that each annotator has its own character which affects the way of perceiving the engagement level. We propose a latent character model which estimates the engagement level and also the character of each annotator as a latent variable. The experimental results show that the latent character model can predict the engagement label of each annotator in higher accuracy than other models which do not take the character into account.

\section{1. は じめ に}

近年，会話ロボットなどの知的対話システムが様々な 場面で実用化されている，これらのシステムは，質問応 答などの特定のタスクにおいては，適切な応答を生成す ることができる [DeVault 14, Higashinaka 14, Skantze 15, Wilcock 15]. しかしながら，そこでなされるインタラク ションは, 人間どうしの自然なそれとは異なる. 例えば, コマンドなどの小語彙をマイクに向かって丁寧に発話さ れる傾向にある [河原 13]. 将来, 会話ロボットなどが, 社会で人間と共生するためには, 自然でかつ円滑なイン タラクションを指向する必要がある.

対話システムとのインタラクションに求められる要素 の一つとして, 本論文では対話におけるエンゲージメン トを扱う。エンゲージメントとは, 対話参与者間におい て, コミュニケーションが成立, 維持, 終了する過程を表 す [Cerrato 16, Sidner 02, Sidner 05]. つまり，エンゲー ジメントが成立している場合には，参与者間でのコミュ
ニケーションの質が保証されることになる．ヒューマン・ コンピュータ・インタラクションの分野では, ユーザの状 態に焦点があてられており，どの程度対話に対して興味 や意欲があり，対話の継続を望んでいるかを表す指標と してエンゲージメントが用いられている. ユーザのエン ゲージメントを推定することで，適応的な対話システム の行動やふるまいを生成することが考えられる。この適 応的な行動やふるまいは, 社会的スキル [Breazeal 04] と 呼ばれ，人間との共生実現を目指す対話システムにとっ て重要な能力であるといえる.

本論文では，ユーザが聞き手であるときの，そのふる まいに基づいてエンゲージメントの推定を試みる．聞き 手のふるまいとは，相槌，笑い，うなずき，視線などを表 す.これらのふるまいは, 話し手の発話に対する聞き手の 反応であるだけでなく, 聞き手の心的状態の表出である ともいえる [高梨 09]. したがって，これらのふるまいは エンゲージメントと相関すると期待される. エンゲージ メントの推定モデルを構築するためには，その正解デー 
タが必要である．ユーザの真のエンゲージメントを対話 中に記録することは困難であるため，通常は第三者のア ノテータが対話を後から観察して知覚したエンゲージメ ントで近似する.しかしながら，エンゲージメントの判 断は主観的であり，その結果はアノテータにより異なる ことがしばしばである.この問題に対処するために, ユー ザのエンゲージメントを知覚する側であるアノテータ，ま たは対話システムは，各自のキャラクタを潜在的に保持 しており，このキャラクタはエンゲージメントの知覚に 影響を及ぼす，という仮定をおく，そして，エンゲージ メントの推定のための潜在キャラクタモデルを提案する. このモデルは, 各アノテータのキャラクタを潜在変数と して，キャラクタの分布とエンゲージメントの分布を同 時にデータから学習する。これにより，エンゲージメン トを知覚する要因に関して，アノテータ間での共通部分 または差異を理解することができる．また，各アノテー タに適したエンゲージメントの推定結果を出力すること ができる。

本論文の構成を以下に示す. 2 章では, エンゲージメン 卜の定義とその推定手法についての関連研究を概観する. 3 章では, 本研究で用いる対話データとエンゲージメン トのアノテーションについて述べる. 4 章では, 提案する 潜在キャラクタモデルについて説明する．5 章では，提 案モデルの推定精度を評価する。 また, 実際にデータか ら学習した提案モデルの分布について分析する. 最後に, 本論文のまとめと今後の展望について，6 章で述べる.

\section{2. 関 連 研 究}

エンゲージメントに関する研究の源流は Goffman の文 献 [Goffman 66] まで遡ることができる. その後, 多数の 研究がなされ，その都度エンゲージメントの定義も様々 ではあるが，ある程度の共通点がみられる [Glas 15]. コ ミュニケーションが成立する過程に焦点をあてると, エ ンゲージメントの定義として以下が挙げられる.

"the process by which two (or more) participants establish, maintain, and end their perceived connection" [Sidner 02]

ヒューマン・コンピュータ・インタラクションの分野で は，ユーザの状態に焦点があてられる傾向にあり，エン ゲージメントの推定を想定して，以下のような定義がな されている.

"the value that a participant in an interaction attributes to the goal of being together with the other participant(s) and of continuing the interaction" [Poggi 07]

"how much a participant is interested in and attentive to a conversation" [Yu 04]
エンゲージメントの推定はこれまでに様々な研究で取 り組まれてきた。多くの場合で, エンゲージメントが高 いか否かの二值分類問題として定式化されている．特徵 量には，言語情報は音声認識誤りや背景雑音などの影響 を受けるため, 非言語情報が主に用いられてきた。本研 究で扱う聞き手のふるまいもこの背景に基づく. 先行研 究で最も用いられてきた特徵量は, 視線のふるまいであ る [Bohus 10, Morency 06, Nakano 10, Peters 05]. 視線の ふるまいは視覚的な注意の表出であり, エンゲージメン トと相関すると考えられる [Langton 00]. 他の特徵量と して, 音響特徵量 [Yu 04], 空間位置情報 [Michalowski 06], 頭部や体の方向 [Kuno 07] などが検討されてきた.

エンゲージメントの推定モデルとして, 近年ではルー ルベースではなく機械学習によるアプローチがとられて いる. Yu ら [Yu 04] は, 電話会話における音響特徵量に ついて, サポートベクトルマシン $(\mathrm{SVM})$ や隠れマルコ フモデル（HMM）を用いてエンゲージメントを推定し た. Nakano ら [Nakano 10] や石井ら [石井 11] は, エー ジェントがユーザに対して商品説明を行う場面において, ユーザの視線のふるまいを N-gram 遷移により表現し, エ ンゲージメントに基づくクラスタリングや， SVM によ るエンゲージメントの推定を行った．Xu ら [Xu 13] は, 移動型ロボットとの対話において, 音響特徵量, 頭部方 向, ユーザとロボットとの距離などのマルチモーダル特 徵量を SVM によりモデル化することでエンゲージメン トを推定した。ここでのエンゲージメントは, ユーザがロ ボットとの会話を開始しようとする，または発話権を取 得しようとする程度を表していた。千葉ら [千葉 16] は, Wizard-of-Oz (WOZ) 形式のインタビュー対話において, 音響, 言語, 画像のマルチモーダル特徵量を, SVM, ラ ンダムフォレスト，ニューラルネットによってモデル化 することで, インタビューを受ける側の対話意欲度を推 定した. また, Huang ら [Huang 16] の研究のように, 人 間どうしの対話におけるエンゲージメントの推定も取り 組まれている。ここでは, 対話参与者の画像データを特 徵量とする畳み込みニューラルネットが推定モデルとし て用いられた。

最近では, エンゲージメントを推定した後に, 対話シ ステムがどのような行動およびふるまいを生成するべき かについての研究も着手されている. 前述の Xu らの研究 [Xu 13] では, 推定したエンゲージメントに応じてター ンテイキングにおけるふるまいが制御されていた。たと えば, 対話システムの発話中に, ユーザのエンゲージメ ントが高いと判断した場合には, ユーザへ発話権を譲る, などの機能が実装された. 被験者実験の結果より, 対話 システムの人間らしさや知的さなどの主観評価が有意に 向上することが確認された. Yu ら [Yu 16] は, WOZ 形 式の対話において, 人手により判断されたエンゲージメ ントに応じて対話戦略を切り替える対話システムを実装 した。たとえば，ユーザのエンゲージメントが低下した 
場合には, 現在の対話モジュールを別のものへとランダ ムに切り替える。これにより, 被験者実験では, システ ム発話の適確さなどの主観評価が向上した。また，遠隔 操作されたアンドロイドとの対話において，ユーザのエ ンゲージメントと, 直後のターンテイキングに関するふ るまいとの関係について分析が行われた [Inoue 16a]. そ の結果, ユーザのエンゲージメントが高い場合には, 直 後のユーザのターンにおける継続時間長とアンドロイド 側がうつ相桘の頻度が増加することがわかった。本研究 では，エンゲージメントを推定した後の対話システムの 行動およびふるまいについては扱わないが, エンゲージ メントレベルを推定する目的は上記の研究と同様である.

本研究では, 多様なふるまいからエンゲージメントを 推定する. 先行研究の多くは, 視線などの単独のふるま いを用いるか, センサーから得られた音響や画像の信号 情報をそのまま用いる場合がほとんどである.ここでの ふるまいとは, 信号情報とエンゲージメントとの中間状 態に相当し, 客観的に検出可能なものである.ただし, ここでは聞き手のふるまい，つまり相槌，笑い，うなず き，視線などの非言語的ふるまいに焦点をあてる．多様 なふるまいに基づくエンゲージメントの推定モデルを構 築することで, これらの関係性について調べる.この関 係性が明らかになれば, 将来, 対話システムが自身のエ ンゲージメントを表現するときに, 適切なふるまいを用 いることができると期待される.

さらに本研究では, アノテータ間でのエンゲージメン トの判断の違いについて検討する. 先行研究では, 複数 のアノテータによるエンゲージメントのアノテーション が行われていた。しかしながら, エンゲージメントの判 断は主観的であり，アノテータ間での不一致も散見され る. 最終的には多数決, または一致した箇所のみを用い るなどの方法がとられ，アノテータ間での判断の違いは 検討されていなかった。これに対して, アノテータ間で の判断の違いを考慮した推定モデルを提案する.これに より, 推定精度の向上だけでなく, アノテータ間の判断 傾向の相違点や共通点をデータから学習および理解する ことが可能になる. エンゲージメントの推定以外のタス クにおいて, アノテータ間での判断の違いを考慮した従 来研究について述べる. Ozkan ら [Ozkan 10, Ozkan 11] は, 相槌の予測において, アノテータ毎に予測モデルを 作成し, 各モデルの予測結果を潜在変数により統合する 二段階の手法を提案した. 本研究で提案するモデルは, 上 記のようにアノテータ毎にモデルを作成するのではなく, 潜在変数とそれに応じた予測モデルを同時にデータから 学習する. したがって, 各アノテータの学習データが少 ない場合でも, モデルの学習が頑健であることが期待さ れる. 熊野ら [Kumano 13, 熊野 17] は, 対話行動情報に 基づく共感状態の推定において, アノテータの特性（性 格特性）による判断傾向の違いをモデル化した. 正解ラ ベルが与えられたもとで, アノテータの特性と対話行動

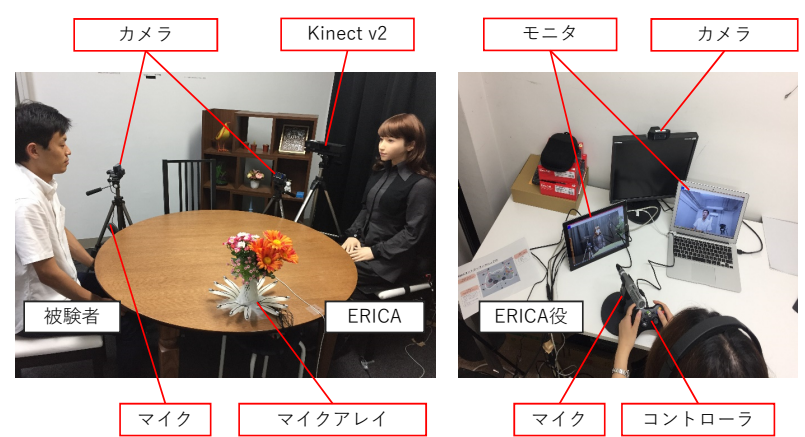

図 1 対話収録の様子

情報は独立であると仮定して，アノテータの特性に基づ く推定と，対話行動情報に基づく推定とをそれぞれ独立 にモデル化した. 本研究では, アノテータの特性と入力 である聞き手のふるまいには依存性がある（アノテータ によってふるまいのとらえ方が異なる）とみなし，これ らを同時に扱うモデルを提案する.ただし，熊野らの手 法は未知のアノテータに対しても, アノテータの性格特 性を指定すれば，これに応じた推定が可能である。

\section{3. エンゲージメントのアノテーション}

エンゲージメントをアノテーションするために用いた 対話データについて述べる。我々は, 自律型アンドロイ ド ERICA [Glas 16, Inoue 16b] を用いたヒューマン・ロ ボット・インタラクションコーパスの構築に取り組んでい る. 今回用いた対話データは, 被験者と遠隔操作された ERICA との一対一対話である。ここでは, ERICAを遠 隔操作した別の被験者を ERICA 役と呼ぶ. 対話のシナリ オは以下の通りである. ERICA は, ある研究室の秘書で あり, 被験者はその研究室の教授に用事があり来訪した. しかし, 教授は不在のため, 教授が戻るまで ERICA と対 話をする. ERICA のふるまいを統制するための ERICA 役への教示として, 対話の進め方, 社会的役割, 研究室 に関する背景知識を伝えた。対話の進め方として, 来訪 者の用件が主題ではあるが，その際に雑談をしてもよい と伝え, またそのための話題一覧を与えた. 話題は, 天気 や研究室へどのようにして来たのか, などの初対面対話 でよく見られるものを選んだ. 研究室秘書の社会的役割 として，来訪者の目的が達成されるようにすること，好 意的に接すること, 終了後に来訪者の用件やどのように 対応したかを報告すること，などを示した．研究室に関 する背景知識として, 当該研究室の教員や学生に関する 情報, また大学秘書に関する一般常識を与えた. 対話の 長さは約 10 分である. 図 1 に対話の様子, および収録 に用いたセンサなどを示す。両者は椅子に座り，テーブ ルを挟んで対面し, ERICA 役はその様子を映像と音声 でモニタリングした. ERICA 役は口元のマイクに向かっ て発話し，その音声は ERICA 本体の近くに設置したス 
ピーカからそのままリアルタイムに再生される. ERICA 役の発話の音韻情報を基に, ERICA の発話中の口唇およ び頭部動作を自動的に生成している [Ishi 12, 境 16]. ま た，ERICA 役は ERICA のうなずきや視線のふるまいを 手元のコントローラによって操作した。収録に用いたセ ンサは, ショットガンマイクロフォン, 16 チャネルマイ クロフォンアレイ, RGB カメラ, Kinect v2 である. 収録 した対話データに対して, 発話, 相桘, 笑い, フィラー, うなずき, 視線, 談話行為, 隣接ペア, ターンなどの情 報を人手により付与した.

本研究では, 上記の対話コーパスから 20 セッションを 用いてエンゲージメントのアノテーションを行った。こ の 20 セッションでは, 被験者はすべて異なる人物であっ たが, ERICA 役は複数人が交代で務めた。被験者の年代 は 10 代から 70 代までの男性 8 名, 女性 12 名であった. ERICA 役は 20 代から 30 代の女性 6 名であった。これ らすべての対話参加者は日本語母語話者であった。

エンゲージメントのアノテーションは，上記の対話に は参加しなかった別の女性 12 名により行ってもらった。 彼女らはすべて大学学部または大学院に所属している. 以下，彼女らをアノテータと呼ぶ. 各対話セッションに 12 名のうちの 5 名のアノテータをランダムに割り当て た.つまり，各アノテータは 8 または 9 セッションのア ノテーションを行った.アノテータへの指示は以下の通 りである. エンゲージメントの定義は先行研究にならい, 「どの程度対話に興味や意欲があり, 対話の継続を望んて いるか」とした。アノテータには, ERICA 役の視点に立 ち，被験者正面を映した映像と音声を確認しながら，工 ンゲージメントを判定してもらった．具体的には，以下 の条件をすべて満たした瞬間に手元のボタンを押しても らった。

（1）被験者が ERICA の話を聞いているとき，つまり 聞き手であるとき

（2）被験者が聞き手のふるまいを表出しているとき

(3) エンゲージメントが高くなったと判断したとき

上記を判断するために，アノテータにいくつかの補助情 報を提示した。まず，(1)のために，被験者が聞き手であ るときの時間区間を，映像の下に再生時間と連動する形 で表示した。これにはターンの情報を用いた。また，(2) のために，予めエンゲージメントと相関すると考えられ る聞き手のふるまいのリストを提示した。このリストに は，表情，笑い，視線，相桘，うなずき，姿勢，肩の動き， 腕・手の動きを含めた。ただし，最終的にアノテータか ら付与されるラベルは, エンゲージメントが高くなった 瞬間の時間情報のみである。ふるまいの表出の判断につ いては,アノテーション作業の効率性から記録しなかっ た。したがって，このアノテーション作業は対話データ と同じ時間で行うことができる．機械学習を行うために は，大量のデータを効率的に収集する必要がある。その ため, 必要かつ重要な情報をできるだけ効率的に収集す
表 1

\begin{tabular}{|c|c|}
\hline 聞き手のふるまい & 回数 \\
\hline 表情 & 77 \\
\hline 相槌 & 67 \\
\hline うなずき & 65 \\
\hline 視線 & 40 \\
\hline 笑い & 39 \\
\hline 姿勢 & 32 \\
\hline 肩の動き & 3 \\
\hline 腕・手の動き & 2 \\
\hline その他 & 4 \\
\hline
\end{tabular}

る方法として, このアノテーション方法を着想した．各 セッションのアノテーション作業後に，アノテータに対 してアンケート調査を行った。アンケートの内容は, エ ンゲージメントの判断方法, アノテーション作業の簡易 さ，アノテーション結果に対する自信度などである。ア ノテーション作業の簡易さは, 7 点の間隔尺度（ 1 =と ても難しい, 7 =とても簡単) で, 平均 3.61, 標準偏差 2.02 であった。また，アノテーション結果に対する自信 度は，同様の尺度（ 1 =全く自信がない， $7=$ とても自 信がある）で, 平均 3.67 , 標準偏差 1.86 であった. した がって， ある程度の簡易さと結果への自信があるといえ る一方で, エンゲージメントの判断は容易ではないこと もうかがえる.

アノテーション結果の概要を以下に示す. 1 セッショ ンあたりの 1 人のアノテータがボタンを押した回数の平 均は 18.13 , 標準偏差は 12.88 である.このばらつきは, セッションまたはアノテータによるものかを比較した。ま ず，各セッションにおけるアノテータ間での平均回数を求 めたところ，この值のセッション間での標準偏差は 8.08 であった。 また，各アノテータにおけるセッション間で の平均回数を求めたところ, この值のアノテータ間での 標準偏差は 6.99 であった。したがって，セッション間だ けでなく，アノテータ間でもボタンを押す回数にある程 度のばらつきがあるといえる，アノテータ間での一致率 も算出した。一致率を算出するために, ERICA のター ンを一致率を判断する単位とした，つまり，ある ERICA のターン内で，あるアノテータがボタンを 1 回以上押せ ば，そのターンはエンゲージメントが高いとみなした。 ERICA のターン数は 1 セッションあたりの平均 33.35 回 である. 各セッションですべてのアノテータのペアについ て Cohen のカッパ係数を求めた。これを全セッションで のすべてのペアについて平均をとると 0.338 であり, 標 準偏差は 0.215 であった。したがって, アノテータ間で の一致率は高いとは言えず，アノテータ毎にエンゲージ メントの判断傾向が異なることが推察される. アノテー ション作業後のアンケート調査では, どのふるまいがエ ンゲージメントが高いと判断するときに有用であったか を複数選択してもらった。回答結果を表 1 に示す。ただ 
し，このアンケート調査は計 100 回（5人のアノテータ に対して 20 セッション) 行ったものである。この結果 から, 表情, 相槌, うなずき, 視線, 笑い, 姿勢がエン ゲージメントに相関すると考えられる. ふるまいとエン ゲージメントとの関係についてデータのみから分析する ことも考えられるが, 可能性があるすべてのふるまいに ついてのアノテーションデータが必要である. 本研究で は, 関係するふるまいを発見するためにアンケート調査 を採用した，後の実験では，上記のふるまいのうち，相 槌, うなずき, 視線, 笑いの 4 種類について, その生起を 人手によりアノテーションしたものを特徴量として用い る. 表情と姿勢はその曖昧性からアノテーション作業が比 較的困難であるため今回は用いないが，将来的には特徵 量に加える予定である. ここでの相槌の定義は, Den ら の分類 [Den 11] における, 応答系感動詞と感情表出系感 動詞に対応する. また, 視線のふるまいは, ある ERICA のターン内で, ERICA の頭部への連続注視時間が 10 秒 以上の場合に生起とした。この 10 秒は連続注視時間の ヒストグラムの分布から, ある程度の数が生起すること を確認したうえで判断した。ただし， 0.5 秒以下の視線 の逸脱は無視した. 全セッションの ERICA の各ターン において，エンゲージメントが高いと判定したアノテー タの人数と, これら 4 種類のふるまいの生起とのスピア マンの順位相関係数は, それぞれ相槌が 0.381 , 笑いが

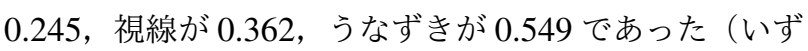
れも $p<0.001$ ).

\section{4. 潜在キャラクタモデルによるエンゲージメ ントの推定}

前章のアノテーションの結果からわかるように, エン ゲージメントは，それを知覚する側（アノテータ）の主 観に左右される，つまり，アノテータ毎に非言語行動の 解釈の方法が異なると推察される. この要因として文化, 性別, 性格などの違いが挙げられる.ここでは, アノテー タの性格 (キャラクタ) の違いが主であると考える. キャ ラクタを分類する軸として, Big Five と呼ばれる 5 つの 因子, 外向性, 情緒不安定性, 開放性, 誠実性, 調和性 がある [Barrick 91]. また，このキャラクタを将来的に対 話システムに実装することで, 設定されたキャラクタに 応じたエンゲージメントの推定, および適応的な行動や ふるまいの生成が期待される。 以上より，アノテータ間 でのキャラクタの違いを考慮したエンゲージメントの推 定モデルを検討する.

問題設定について述べる.エンゲージメントの推定は 対話システム側 (ERICA) のターン毎に行う. 入力は, 前章で定義した聞き手の各ふるまいの生起を表す二值と する. 入力特徵量の表現方法に関しては, 将来的には, 複 数回の生起を表現するための非負の整数や，ふるまいの 自動検出を想定した連続值へと拡張する予定である. 出

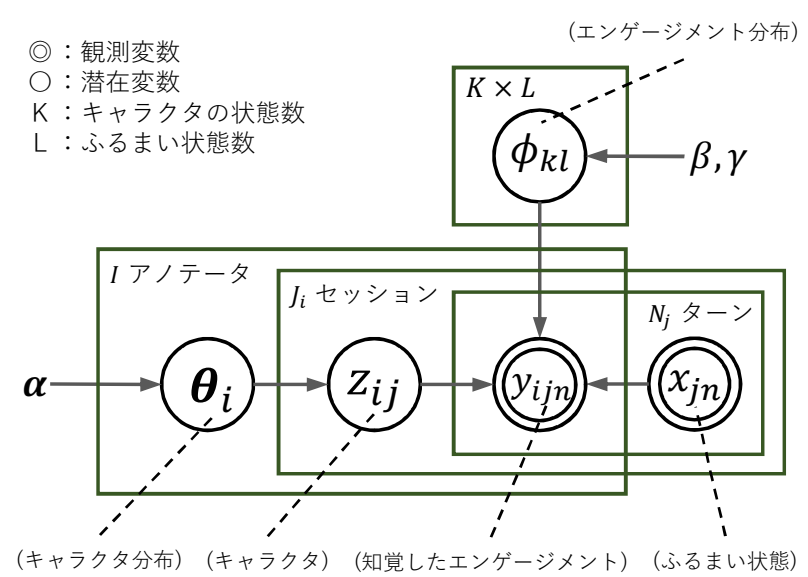

図 2 潜在キャラクタモデルのグラフィカルモデル

力はエンゲージメントが高いか否かの二值である.これ は前章のアノテーション結果に対応する．ただし，ある ターンでアノテータが手元のボタンを 1 回以上押した場 合に，そのターンはエンゲージメントが高いとする.

エンゲージメントを判断する側である対話システム（ア ノテータ）のキャラクタを潜在変数とする階層ベイズモ デルを提案する．本論文では，これを潜在キャラクタモ デルと呼ぶ.このモデルは潜在ディリクレ配分法（LDA: latent dirichlet allocation）[Blei 03] などの潜在変数モデ ルを参考にしている. エンゲージメントとキャラクタの 分布を同時にデータから学習することで, アノテータ毎 に異なる適切なエンゲージメントの判断結果を出力する. 例えば，ユーザの笑いが生起した場合に，あるキャラク タを持つアノテータはその笑いからエンゲージメントが 高いと判断するが，別のキャラクタを持つアノテータは 異なった判断をする，といったことが可能になる．つま り, 複数のキャラクタによるエンゲージメントの判断を 同時に推定することができる，以下では，複数のふるま いの統合方法について, 特徵量レベルの統合 (4.1 節) と 確率レベルの統合 $(4.3$ 節) の 2 種類について述べる. ま ず，前者を基にして潜在キャラクタモデルを説明する.

\section{$4 \cdot 1$ 階層ベイズモデル}

潜在キャラクタモデルのグラフィカルモデルを図 2 に 示す．生成過程を以下に述べる．まず，各アノテータに おいて，キャラクタの分布が生成される.

$$
\boldsymbol{\theta}_{i} \sim \operatorname{Dir}(\boldsymbol{\alpha}), 1 \leq i \leq I
$$

ただし， $i$ はアノテータのインデクス，I はアノテータの 数, Dir はディリクレ分布, $\boldsymbol{\alpha}$ はハイパーパラメータを それぞれ表す．また， $\boldsymbol{\theta}_{i}$ の各要素は下記で定義される.

$$
\boldsymbol{\theta}_{i}=\left(\theta_{i 1}, \cdots, \theta_{i k}, \cdots, \theta_{i K}\right)
$$

ここで, $K$ はキャラクタの状態数に対応する. 続いて, 各 アノテータが，各対話セッションにおいて持つキャラク 
タが生成される.

$$
z_{i j} \sim \operatorname{Cat}\left(\boldsymbol{\theta}_{i}\right), 1 \leq j \leq J_{i}
$$

ただし, $j$ はセッションのインデクス, $J_{i}$ は $i$ 番目のアノ テータがアノテーション作業を行ったセッション数, Cat はカテゴリカル分布をそれぞれ表す．つまり，アノテー タ毎に 1 つのキャラクタの分布 $\boldsymbol{\theta}_{i}$ を持ち，これに基づい て, アノテータとセッションの組合せ毎にキャラクタ $z_{i j}$ が 1 つ決まる. 各アノテータが持つキャラクタは各対話 セッション内では一貫して同じであるとする.ここで, $j$ 番目のセッションでの, $n$ 番目の対話システムのターン において，ふるまい $b$ の生起を $x_{b j n} \in\{0,1\}$ で表す。ま た, 各ふるまいの生起の組合せ $x_{j n}$ をふるまい状態と呼 び，以下で表す。

$$
x_{j n}:=\operatorname{comb}\left(x_{1 j n}, \cdots, x_{b j n}, \cdots, x_{B j n}\right), 1 \leq n \leq N_{j}
$$

ただし, $B$ はふるまいの種類数, $N_{j}$ は $j$ 番目のセッショ ンにおける対話システムのターン数, $\operatorname{comb}(\cdot)$ は.の組 合せの種類をそれぞれ表す．また，ふるまい状態 $x_{j n}$ が とり得る状態数 $L$ は, 今回の問題設定では $2^{B}$ である. キャラクタ $k$ とふるまい状態 $l$ の組合せについて, エン ゲージメントの分布 $\phi_{k l}$ が生成される.

$$
\phi_{k l} \sim \operatorname{Beta}(\beta, \gamma), 1 \leq k \leq K, 1 \leq l \leq L
$$

ただし, Beta はベータ分布, $\beta$ と $\gamma$ はハイパーパラメー タをそれぞれ表している。この分布は $K \times L$ 個用意さ れる. キャラクタ $z_{i j}$ を持つアノテータがふるまい状態 $x_{j n}$ を観察したとき, そのアノテータはエンゲージメン ト $y_{i j n}$ を知覚する。

$$
y_{i j n} \sim \operatorname{Ber}\left(\phi_{z_{i j} x_{j n}}\right)
$$

ただし，Berはベルヌーイ分布を表す．

モデルを学習するときには, ふるまい状態 $x_{j n}$ とエン ゲージメント $y_{i j n}$ は観測変数であり, キャラクタ $z_{i j}$ は 潜在変数として推定する. 上記の変数のデータセットが 与えられたときの条件付き分布は以下で表される.

$$
p(\boldsymbol{Y}, \boldsymbol{Z}, \boldsymbol{\Theta}, \boldsymbol{\Phi} \mid \boldsymbol{X})=p(\boldsymbol{Y} \mid \boldsymbol{X}, \boldsymbol{Z}, \boldsymbol{\Phi}) p(\boldsymbol{Z} \mid \boldsymbol{\Theta}) p(\boldsymbol{\Theta}) p(\boldsymbol{\Phi})
$$

ただし，これらの変数はそれぞれの小文字で表される変数 のデータセットに対応し， $\Theta$ と $\boldsymbol{\Phi}$ は分布のパラメータ集 合である. また，ふるまい状態のデータセット $\boldsymbol{X}$ はテスト 時にも与えられる. (7) 式の右辺において, $p(\boldsymbol{Y} \mid \boldsymbol{X}, \boldsymbol{Z}, \boldsymbol{\Phi})$ はふるまい状態とキャラクタの組合せの各々について，エ ンゲージメントが高いとどの程度知覚されるか, $p(\boldsymbol{Z} \mid \boldsymbol{\Theta})$ は各アノテータがどのキャラクタを持つのかをそれぞれ 表している．このモデルはマルコフ連鎖モンテカルロ法 （MCMC）によって学習データから各分布を推定するこ とができる．キャラクタとエンゲージメントの分布のパ
ラメータ集合 $\Theta$ と $\boldsymbol{\Phi}$ はサンプリング結果の期待值によ り推定する.

推定したモデルをテストするときには，アノテータの インデクス $i$, ふるまい状態 $x_{t}$, 学習データから推定し

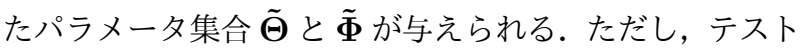
時の対話システムのターンのインデクスを $t$ で表す。こ れらから未知のエンゲージメント $y_{i t}$ の予測分布を以下 の式で求める.

$$
p\left(y_{i t} \mid x_{t}, i, \tilde{\boldsymbol{\Theta}}, \tilde{\mathbf{\Phi}}\right)=\sum_{k=1}^{K} \tilde{\theta}_{i k} \tilde{\phi}_{k x_{t}}
$$

ただし, $\tilde{\theta}_{i k}$ は $i$ 番目のアノテータがキャラクタ $k$ を持 つ確率, $\tilde{\phi}_{k x_{t}}$ はふるまい $x_{t}$ がキャラクタ $k$ を持つアノ テータにエンゲージメントが高いと知覚される確率につ いて，学習データから推定した分布である. エンゲージ メントが高いと知覚される確率 $p\left(y_{i t}=1 \mid x_{t}, i, \tilde{\boldsymbol{\Theta}}, \tilde{\boldsymbol{\Phi}}\right)$ が 闇值以上の場合に, $t$ 番目のターンをエンゲージメントが 高いと出力する. また, このモデルは未知のアノテータ については，エンゲージメントの推定を行うことができ ない。しかし, 熊野らの手法 [Kumano 13, 熊野 17] のよ うに，アノテータの性格特性などをアノテータのインデ クスの代わりとすることで対応可能になると考えられる.

\section{$4 \cdot 2$ 文脈情報の利用}

直前のターンでのエンゲージメントの推定結果を利用 することで, 文脈情報を考虑したものへと提案モデルを 拡張する.ここでの仮定は, エンゲージメントはいくつか のターンにわたって継続する場合もあることである. 例 えば, 一度エンゲージメントが高くなると, 以降のター ンも継続してエンゲージメントが高くなると考えられる. 前章でのモデルの定義を以下のように拡張する. (5) 式の エンゲージメントの分布と (6) 式の知覚されるエンゲー ジメントはそれぞれ以下のように表される.

$$
\begin{aligned}
\phi_{k l y} & \sim \operatorname{Beta}(\beta, \gamma), y \in\{0,1\} \\
y_{i j n} & \sim \operatorname{Ber}\left(\phi_{z_{i j} x_{j n} y_{i j(n-1)}}\right)
\end{aligned}
$$

ただし，(9) 式での $y$ は, 直前のターンでのエンゲージ メントの推定結果に対応する. また，(7) 式の条件付き分 布は以下となる。

$$
\begin{aligned}
& p\left(\boldsymbol{Y}, \boldsymbol{Z}, \boldsymbol{\Theta}, \boldsymbol{\Phi} \mid \boldsymbol{Y}_{1: n-1}, \boldsymbol{X}\right) \\
& =p\left(\boldsymbol{Y} \mid \boldsymbol{Y}_{1: n-1}, \boldsymbol{X}, \boldsymbol{Z}, \boldsymbol{\Phi}\right) p(\boldsymbol{Z} \mid \boldsymbol{\Theta}) p(\boldsymbol{\Theta}) p(\boldsymbol{\Phi})
\end{aligned}
$$

ただし， $\boldsymbol{Y}_{1: n-1}$ は直前のターンまでのエンゲージメント の判断結果のデータセットを表す. (8) 式のエンゲージメ ントの予測分布は, 再帰的に以下の前向きアルゴリズム 
により求める.

$$
\begin{aligned}
& p\left(y_{i t} \mid x_{t}, i, \tilde{\boldsymbol{\Theta}}, \tilde{\boldsymbol{\Phi}}\right)= \\
& \sum_{k=1}^{K} \tilde{\theta}_{i k} \sum_{y_{i(t-1)} \in\{0,1\}} \tilde{\phi}_{k x_{t} y_{i(t-1)}} p\left(y_{i(t-1)} \mid x_{t-1}, i, \tilde{\boldsymbol{\Theta}}, \tilde{\boldsymbol{\Phi}}\right)
\end{aligned}
$$

\section{$4 \cdot 3$ 確率レベルのふるまい統合}

$4 \cdot 1$ 節では, 複数のふるまいは特徵量の時点で, 組合せ の状態として表現された。ここでは, 各ふるまいを独立 に確率モデルとして表現し, 確率レベルで統合すること を考える. 具体的には, Product of Experts (PoE) [Hinton 02] の枠組みを用いる. 各ふるまいにおけるエンゲージ メントの分布を以下で表す.

$$
\phi_{k b b^{\prime}} \sim \operatorname{Beta}(\beta, \gamma), 1 \leq b \leq B, b^{\prime} \in\{0,1\}
$$

ただし， $b^{\prime}$ はふるまい $b$ の生起に対応する. そして, こ れらを以下の式で統合する.

$$
\phi_{k l}=\frac{\prod_{b}^{B} \phi_{k b b^{\prime}}}{\prod_{b}^{B}\left(1-\phi_{k b b^{\prime}}\right)+\prod_{b}^{B} \phi_{k b b^{\prime}}}
$$

ここで, $4 \cdot 1$ 節でのふるまい状態 $l$ は, ふるまいの種類 $b$ とその生起 $b^{\prime}$ に分解されていることがわかる. このモ デルでは, エンゲージメントの分布の数は, ふるまいの 種類数に対して線形であり, 特徵量レベルの統合に比べ て，ふるまいの種類を容易に増やすことができる．また， このモデルでも, $4 \cdot 2$ 節と同様にして, 直前のターンで の推定結果 $y_{i j(n-1)}$ を文脈情報として利用することがで きる.

\section{5. 評 価 実 験}

提案モデルの有効性を確認するために，3 章で述べた 20 セッションの対話データを用いて交差検定を行った.ここ では，19セッションを学習用，1 セッションをテスト用と した. 各セッションでは 5 人のアノテータによる正解デー タがある.これらの正解データについて, すべて同時に 評価した.ただし, 提案モデルでは, 与えられたアノテー タのインデクス $i$ に応じて, それぞれ異なる推定結果を出 力する. 評価手順は以下の通りである. まず, エンゲージ メントが高いと知覚される確率 $p\left(y_{i t}=1 \mid x_{t}, i, \tilde{\boldsymbol{\Theta}}, \tilde{\boldsymbol{\Phi}}\right)$ の 閾值を変化させて, 以下の式により適合率と再現率の曲 線をテスト用のセッション毎に求める.

$$
\begin{aligned}
& \text { 適合率 }=\frac{\# \mathrm{TP}}{\# \mathrm{TP}+\# \mathrm{FP}} \\
& \text { 再現率 }=\frac{\# \mathrm{TP}}{\# \mathrm{TP}+\# \mathrm{FN}}
\end{aligned}
$$

ただし, \#TP は正解ラベルが正のうちで, これを正しく 推定したターン数, \#FP は正解ラベルが負のうちで, 正
表 2 評価の例（このターンでは, 適合率 $=1 / 2$, 再現率=1/3）

\begin{tabular}{lccccc}
\hline アノテータ $(i)$ & 1 & 3 & 4 & 7 & 10 \\
\hline 正解ラベル & 1 & 1 & 0 & 0 & 1 \\
モデル出力 & 0.45 & 0.61 & 0.39 & 0.55 & 0.41 \\
結果 (閾値=0.50) & FN & TP & TN & FP & FN \\
\hline
\end{tabular}

と誤って推定したターン数, \#FN は正解ラベルが正のう ちで，負と誤って推定したターン数をそれぞれ表す。あ る 1 つのターンにおける評価の一例を表 2 に示す。この ターンでは, 適合率は $1 / 2$, 再現率は $1 / 3$ である. 実際に は，セッション毎に，すべてのターンのデータを用いて この評価を行う. そして, 全セッションでの平均曲線を 求め, その Area Under the Curve (AUC) を評価指標と した。したがって，AUCが高いほど良い推定精度である といえる。また，実際のシステム運用では，各アノテー タに対してどの程度近い推定がなされているかが重要で ある.このための評価指標として，アノテータ毎に F 值 を求めた. $\mathrm{F}$ 值を算出するための閾值として, 上記で求 めたセッション毎の適合率と再現率の曲線において適合 率と再現率が等しくなる点（Equal Error Rate）の值を用 いて，アノテータ毎に適合率と再現率およびその調和平 均である $\mathrm{F}$ 值を求めた。そして, 全セッションにおける 全アノテータの平均 $\mathrm{F}$ 值を評価した。データセット全体 で，エンゲージメントが高いとアノテータにより判断さ れたターン数は 1,140 ，そうではないターン数は 2,195 で あった.したがって，すべてのターンでエンゲージメン トが高いと推定した場合のチャンスレートは 0.342 であ る. また, 入力特徵量は, 3 章で述べたように, 4 種類の ふるまい, 相槌, 笑い, うなずき, 視線の生起について, 人手によりアノテーションしたものである.

提案モデルのパラメータは以下の通りである. キャラ クタの状態数 $(K)$ は 2 から 4 を試した. MCMCの実装 には, PyMC $2.36^{* 1}$ を用いた. MCMC のサンプリングア ルゴリズムにはメトロポリス・ヘイスティングス法を用 いた. サンプリング回数は 30,000 回で, うち 20,000 回 はバーンインとした。事前分布はすべて一様分布とした.

\section{$5 \cdot 1$ キャラクタの効果}

キャラクタの違いを考慮することによる効果を比較し た。ただし，4.2 節で述べた文脈情報はここでは用いな い.これについては次節で比較を行う. 比較手法は, ロジ スティック回帰モデルと, 潜在キャラクタモデルと同じ枠 組みでキャラクタ数が 1 の場合 $(K=1)$ である. ロジス ティック回帰モデルは scikit-learn 0.18.1*2 を用いて実装 した. また，ロジスティック回帰モデルを学習する際の教 師ラベルの使用方法は, アノテータ非依存とアノテータ 依存の 2 種類を検討した. 前者のアノテータ非依存では, すべてのアノテータのデータをそのまま用いて，1 1 の

$\begin{array}{ll}* 1 & \text { https://github.com/pymc-devs/pymc } \\ * 2 & \text { http://scikit-learn.org/stable/ }\end{array}$ 


\begin{tabular}{|c|c|c|c|c|}
\hline & 手法 & $K$ & AUC & $\mathrm{F}$ 值 \\
\hline \multirow{4}{*}{ ロジスティック回帰 } & アノテータ非依存 & & 0.569 & 0.496 \\
\hline & アノテータ非依存（多数決） & & 0.567 & 0.491 \\
\hline & アノテータ依存 & & 0.597 & 0.440 \\
\hline & アノテータ依存（投票） & & 0.550 & 0.484 \\
\hline \multirow{8}{*}{ 潜在キャラクタモデル } & \multirow{4}{*}{ 特徵量レベル } & 1 & 0.568 & 0.497 \\
\hline & & 2 & 0.640 & 0.535 \\
\hline & & 3 & 0.645 & 0.547 \\
\hline & & 4 & 0.643 & 0.545 \\
\hline & \multirow{4}{*}{ 確率レベル } & 1 & 0.569 & 0.494 \\
\hline & & 2 & 0.642 & 0.529 \\
\hline & & 3 & 0.642 & 0.520 \\
\hline & & 4 & 0.643 & 0.518 \\
\hline
\end{tabular}

モデルを学習する．テスト時には，複数のアノテータに 対して同一のモデルを用いるため，アノテータのインデ クスによらず同じ推定結果を出力する. さらに, 多数決 によるラベリング手法と比較するために，アノテータ非 依存では，アノテータ間での多数決ラベルによるモデル の学習も試みる. 具体的には， 5 人のアノテータのうち 3 人以上がエンゲージメントが高いと判断したものには 正， 2 人以下の場合には負のラベルを用意して，これを 教師ラベルとしてモデルを学習する. 後者のアノテータ 依存では，各アノテータによる学習データのみを用いて， アノテータ毎にモデルを学習する，テスト時には，各ア ノテータに対応するモデルを用いて評価する。この方法 では，アノテータ毎の傾向を学習できるが，学習データ 数は少なくなる．また，集合知による手法と比較するた めに，アノテータ依存では，他のアノテータのモデルに よる推定結果の統合も試みる。具体的には，推定対象で あるアノテータ以外の 4 人のアノテータのアノテータ依 存モデルを用いて推定を行い，エンゲージメントが高い と判断する確率の平均をとったものを出力とした。ロジ スティック回帰モデルでは，学習データを 9 対 1 に相当 するようにセッション単位で分割して，前者をモデルの 学習, 後者を L2 ノルム正則化項の重み（ハイパーパラ メータ）のチューニングに用いた。この重みの值の範囲 は, $\left\{10^{n} \mid n=-3,-2,-1,0,1,2,3\right\}$ であり, AUC が 最も高くなる值を選択した。

結果を表 3 に示す。まず，ロジスティック回帰モデルに おいて，セッション毎の AUCではアノテータ依存が，ア ノテータ毎の F 值ではアノテータ非依存が，それぞれ高 い精度を示した。ただし，アノテータ依存ではデータ数 が少ないことから，モデルが十分に学習されていないと 推察される．実際に，出力された事後確率はアノテータ 毎にその範囲が大きく異なっていたため，閾值を変化さ せると, 特定のアノテータにはすべて正, 別のアノテー タにはすべて負と推定するセッションがしばしばみられ た。このような推定であっても，今回のタスクでは AUC

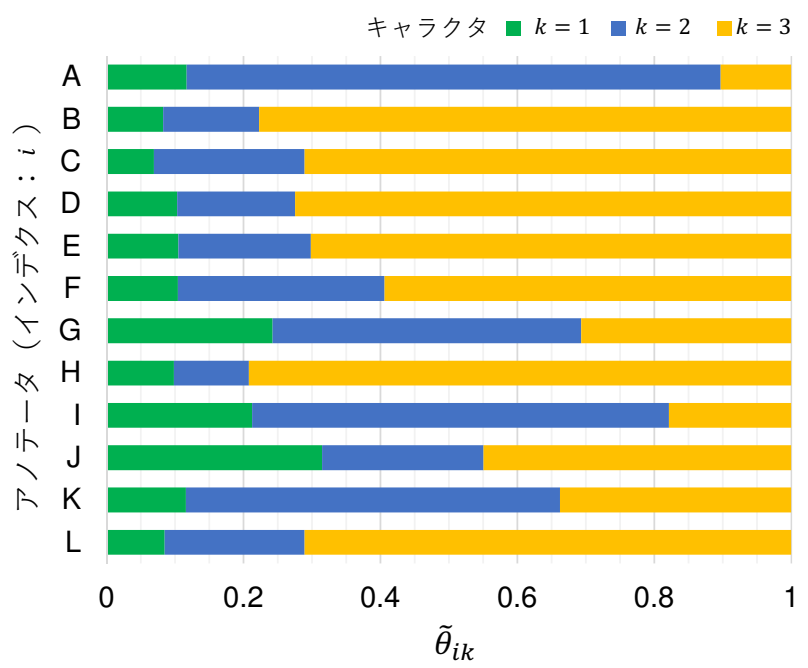

図 3 各アノテータのキャラクタの分布

が多少の改善を示すため, AUC および F 值の両方を改 善することが望ましいといえる。また，アノテータ非依 存（多数決）とアノテータ依存（投票）では，大きな精 度改善は特にみられなかった。次に，潜在キャラクタモ デル $(K \geq 2)$ に注目すると，いずれの評価指標におい ても，比較手法に比べて推定精度が向上していることが わかる. したがって，アノテータ間でのキャラクタの違 いを考慮することは有効であるといえる．潜在キャラク タモデルにおけるふるまいの統合手法を比較すると，若 干ではあるが特徵量レベルの方が確率レベルよりも高い 精度を示した。このことは, 特徵量の段階で各ふるまい の共起を考慮する必要があることを示唆している. キャ ラクタの状態数 $K$ を変化させたときの推定精度を比較す ると, 有意な差はみられなかった。したがって，ここで のキャラクタは潜在的に 2 または 3 程度の次元で表現で きると推察される.

潜在キャラクタモデルの学習例について分析する.こ こでの例は, キャラクタ数が 3 で, 特徴量レベルの統合 


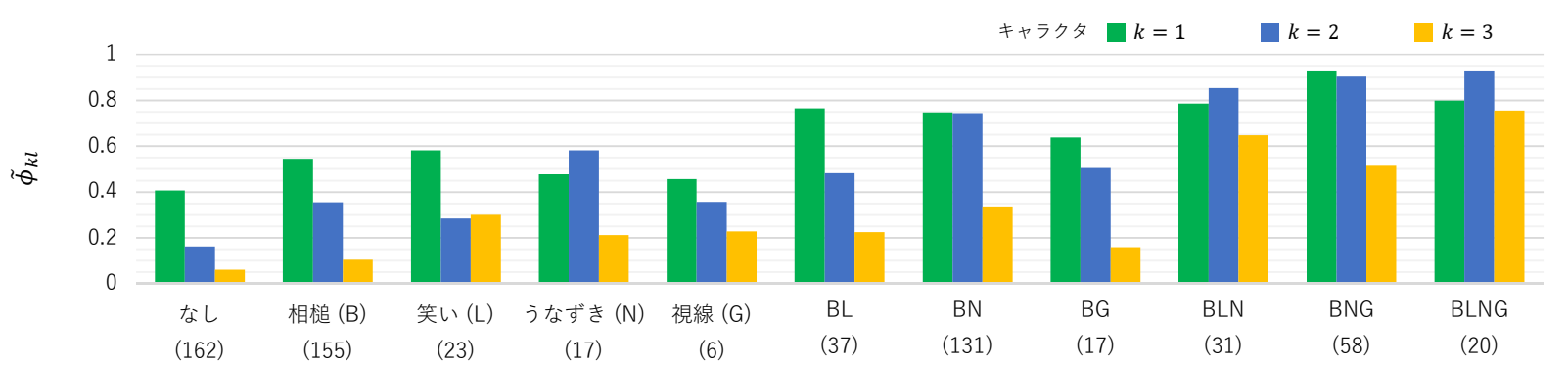

ふるまい状態 (インデクス： $l$ )

図 4 各ふるまい状態に対してエンゲージメントが高いと各キャラクタが知覚する確率 (ラベル下の括弧内はコー パス内での頻度）

表 4 文脈情報の効果 (セッション毎の Area Under the Curve およびアノテータ毎の F 值の平均)

\begin{tabular}{|c|c|c|c|c|c|}
\hline & 手法 & $K$ & 文脈情報 & AUC & $\mathrm{F}$ 值 \\
\hline \multirow{4}{*}{ ロジスティック回帰 } & アノテータ非依存 & & & 0.569 & 0.496 \\
\hline & アノテータ非依存（多数決） & & & 0.567 & 0.491 \\
\hline & アノテータ依存 & & & 0.597 & 0.440 \\
\hline & アノテータ依存（投票） & & & 0.550 & 0.484 \\
\hline \multirow{4}{*}{ 条件付確率場（CRF） } & アノテータ非依存 & & $\checkmark$ & 0.599 & 0.554 \\
\hline & アノテータ非依存（多数決） & & $\checkmark$ & 0.586 & 0.533 \\
\hline & アノテータ依存 & & $\checkmark$ & 0.609 & 0.447 \\
\hline & アノテータ依存（投票） & & $\checkmark$ & 0.566 & 0.505 \\
\hline \multirow{8}{*}{ 潜在キャラクタモデル } & \multirow{4}{*}{ 特徵量レベル } & \multirow{2}{*}{1} & & 0.568 & 0.497 \\
\hline & & & $\checkmark$ & 0.619 & 0.552 \\
\hline & & \multirow{2}{*}{3} & & 0.645 & 0.547 \\
\hline & & & $\checkmark$ & 0.667 & 0.565 \\
\hline & \multirow{4}{*}{ 確率レベル } & \multirow{2}{*}{1} & & 0.569 & 0.494 \\
\hline & & & $\checkmark$ & 0.615 & 0.544 \\
\hline & & \multirow{2}{*}{3} & & 0.642 & 0.520 \\
\hline & & & $\checkmark$ & 0.657 & 0.542 \\
\hline
\end{tabular}

の場合である.図 3 にアノテータ毎のキャラクタの分布 $\left(\tilde{\theta}_{i k}\right)$ を示す.いくつかアノテータ間で共通した傾向が みられる. 例えば, アノテータ A と I は似た分布である. また，アノテータ B, C, D, E, H, L の間でも似た分 布を示している. 図 4 に, 各キャラクタにおいて, 各ふ るまい状態が入力されたときにエンゲージメントが高い と知覚する確率 $\left(\tilde{\phi}_{k l}\right)$ を示す.ただし, コーパス全体で の頻度が 5 回以下のふるまい状態は除外した。この例よ り，キャラクタ毎に異なる傾向が学習できていることが わかる. 例えば, 1 つ目のキャラクタ $(k=1)$ は, 相桘 （B）と笑い（L）が，エンゲージメントが高いと知覚する 傾向にあることがわかる．2つ目のキャラクタ $(k=2)$ ではうなずき（N) が，3つ目のキャラクタ $(k=3)$ で は笑い（L）が比較的優位であることがわかる.また， 3 つ目のキャラクタ $(k=3)$ は, エンゲージメントが高い と知覚する確率が他の 2 つのキャラクタに比べて全体的 に低い. すべてのキャラクタに共通して, 複数のふるま いが共起した場合（図の右側）には，エンゲージメント が高いと知覚する傾向にある。

\section{$5 \cdot 2$ 文脈情報の効果}

直前のターンでの推定結果を文脈情報として用いる効果 を比較した。比較手法は, 条件付き確率場 (CRF: conditional random field）と，文脈情報ありの潜在キャラクタモ デルと同じ枠組みでキャラクタ数が 1 の場合 $(K=1)$ で ある. CRF は, CRF suite $0.12 * 3$ を用いて実装した. CRF を学習する際の教師ラベルの使用方法は, 前節と同様に, アノテータ非依存とアノテータ依存の 2 種類を検討した. $\mathrm{CRF}$ の L2 ノルム正則化項の重み（ハイパーパラメータ） は, 前節と同様にして, 学習データセットの 1 割に相当す るセッションを用いてチューニングを行った．前節の結果 に基づいて, 潜在キャラクタモデルにおけるキャラクタ の状態数は 3 に固定した $(K=3)$. 結果を表 4 に示す. 文脈情報を利用することにより，セッション毎の AUC お よびアノテータ毎の $\mathrm{F}$ 值は全体的に向上した。 キャラク タを考慮することによる効果は特徵量レベルの統合でみ られた。また，ふるまいの統合方法の比較についても前 節と同様の傾向がみられ, 特徵量レベルの方が若干の高 い精度を示した。

*3 http://www.chokkan.org/software/crfsuite/ 
表 5 各アノテータが各キャラクタを持つ確率と Big Five 尺度の 各因子とのスピアマンの順位相関係数（一 は $p<0.10 ， *$ * $p<0.05, * *$ * $p<0.01$ をそれぞれ表す.)

\begin{tabular}{cccc}
\hline Big Five 因子 & \multicolumn{3}{c}{ キャラクタ } \\
& $k=1$ & $k=2$ & $k=3$ \\
\hline 外向性 & $0.723^{* *}$ & 0.295 & -0.368 \\
情緒不安定性 & 0.196 & 0.298 & -0.263 \\
開放性 & 0.172 & -0.305 & 0.256 \\
誠実性 & -0.487 & $-0.557^{-}$ & $0.655^{*}$ \\
調和性 & -0.095 & -0.102 & 0.193 \\
\hline
\end{tabular}

\section{$5 \cdot 3$ 主観的なキャラクタとの関係}

潜在キャラクタモデルにより推定したキャラクタの分 布と主観的なキャラクタとの関係について調べた。主観 的なキャラクタを得るために，和田 [和田 96]によって 作成された Big Five 尺度を用いた。これは，60 項目の 7 段階評定から，性格に関する 5 因子，外向性，情緒不 安定性，開放性，誠実性，調和性についての尺度得点を 算出するものである. 3 章のアノテーション作業を実施 するにあたり，各アノテータに対してこの尺度を測定し た. 図 3 で示した各アノテータが各キャラクタを持つ確 率と, Big Five 尺度の各因子との組合せについて，スピ アマンの順位相関係数を求めた。結果を表 5 に示す. 1 つ目のキャラクタ $(k=1)$ では, 外向性と有意な正の 相関がみられた $(p=0.008)$. 藤本らの研究 [藤本 07] では，言語および非言語を通して相手の考えや気持ちを 正しく読み取る「解読力」について，外向性が高い人は 低い人よりも解読力が高いことが示されている．1つ目 のキャラクタ $(k=1)$ は, 図 4 において, 11 個中 7 個 のふるまい状態について, 他の 2 つのキャラクタよりも エンゲージメントが高いと知覚する確率が高かった。し たがって，このキャラクタは，ふるまいの解読力が高い ことが示唆される. また, 誠実性について比較的高い負 の相関係数が示されたが，有意であるとはいえなかった $(p=0.108)$. 2つ目のキャラクタ $(k=2)$ でも，誠実 性について比較的高い負の相関係数が示されたが，こち らも有意であるとはいえなかった $(p=0.060)$. 3つ目 のキャラクタ $(k=3)$ では, 誠実性と有意な正の相関が みられた $(p=0.021)$. 以上より, 潜在キャラクタモデ ルによって推定されるキャラクタの分布が，Big Five 尺度 による主観的なキャラクタと一部相関することがわかっ た。ただし，より多くのアノテータのデータを用いて有 意性を検証する必要があるといえる。

\section{6. おわりに}

本論文では，聞き手の多様なふるまいに基づく対話エ ンゲージメントの推定について述べた。ここでは，エン ゲージメントを知覚する側の内部にキャラクタがあり,こ れが知覚の方法に影響を及ぼすと仮定した。そして，キャ
ラクタを潜在変数とする潜在キャラクタモデルを提案し た. 提案モデルは, キャラクタとエンゲージメントの分 布を同時に推定することができる．実験の結果，キャラ クタの違いを考慮することで，各アノテータに適したエ ンゲージメントの推定ができることを確認した．さらに， 文脈情報を利用することによる精度向上も示した．また， 実際に学習された分布の分析を行い, キャラクタ毎にエ ンゲージメントの推定傾向が異なることも確認した。こ の分布は，自律型アンドロイドのような身体性を伴う対 話ロボットが自身のエンゲージメントを表現する際に有 用であると期待できる.

今後は，ふるまいの自動検出 [Chen 15, Gosztolya 15, Inoue 15, Kaushik 15, Morency 07] を実装して, エンゲー ジメントの推定モデルとの統合を図る。これにより, リ アルタイムでエンゲージメントを推定する対話ロボット の実現を目指す。さらに，関連研究で述べたように，エ ンゲージメントを推定した後の対話システムの行動およ びふるまいについても研究を展開していく予定である.

\section{謝辞}

対話収録，およびアノテーション作業にご協力いただい た皆様に感謝いたします。本研究は，JSPS 科研費（課題 番号：15J07337），ならびに JST ERATO 石黒共生ヒュー マンロボットインタラクションプロジェクト（課題番号 : JPMJER1401）の支援を受けて実施されたものである.

\section{$\diamond$ 参 考 文 献 $\diamond$}

[Barrick 91] Barrick, M. R. and Mount, M. K.: The big five personality dimensions and job performance: A meta-analysis, Personnel Psychology, Vol. 44, No. 1, pp. 1-26 (1991)

[Blei 03] Blei, D. M., Ng, A. Y., and Jordan, M. I.: Latent dirichlet allocation, Journal of Machine Learning Research, Vol. 3, pp. 9931022 (2003)

[Bohus 10] Bohus, D. and Horvitz, E.: Facilitating multiparty dialog with gaze, gesture, and speech, in Proceedings of the International Conference on Multimodal Interfaces and the Workshop on Machine Learning for Multimodal Interaction (ICMI-MLMI), No. 5 (2010)

[Breazeal 04] Breazeal, C.: Social interactions in HRI: The robot view, IEEE Transactions on Man, Cybernetics, and Systems, Vol. 34, No. 2, pp. 181-186 (2004)

[Cerrato 16] Cerrato, L. and Campbell, N.: Engagement in dialogue with social robots, in Proceedings of the International Workshop on Spoken Dialogue Systems (IWSDS) (2016)

[Chen 15] Chen, Y., Yu, Y., and Odobez, J.-M.: Head nod detection from a full 3D model, in Proceedings of the International Conference on Computer Vision Workshops (ICCVW), pp. 136-144 (2015)

[千葉 16] 千葉 祐弥, 伊藤 彰則 : WOZ システムとの対話におけ るユーザの対話意欲の段階識別と特徵量の分析, 人工知能学会研 究会資料 言語 - 音声理解と対話処理研究会 (SLUD), SIG-SLUDB505-02, pp. 7-12 (2016)

[Den 11] Den, Y., Yoshida, N., Takanashi, K., and Koiso, H.: Annotation of Japanese response tokens and preliminary analysis on their distribution in three-party conversations, in Proceedings of Oriental COCOSDA, pp. 168-173 (2011)

[DeVault 14] DeVault, D., Artstein, R., Benn, G., Dey, T., Fast, E., Gainer, A., Georgila, K., Gratch, J., Hartholt, A., Lhommet, M., Lucas, G., Marsella, S., Morbini, F., Nazarian, A., Scherer, S., Stratou, G., Suri, A., Traum, D., Wood, R., Xu, Y., Rizzo, A., and 
Morency, L. P.: SimSensei Kiosk: A virtual human interviewer for healthcare decision support, in Proceedings of the International Conference on Autonomous Agents and Multiagent Systems (AAMAS), pp. 1061-1068 (2014)

[藤本 07] 藤本 学, 大坊 郁夫 : コミュニケーション・スキルに関す る諸因子の階層構造への統合の試み, パーソナリティ研究, Vol. 15, No. 3, pp. 347-361 (2007)

[Glas 15] Glas, N. and Pelachaud, C.: Definitions of engagement in human-agent interaction, in Proceedings of the International Workshop on Engagement in Human Computer Interaction (ENHANCE), pp. 944-949 (2015)

[Glas 16] Glas, D. F., Minaot, T., Ishi, C. T., Kawahara, T., and Ishiguro, H.: ERICA: The ERATO Intelligent Conversational Android, in Proceedings of the IEEE International Symposium on Robot and Human Interactive Communication (RO-MAN) (2016)

[Goffman 66] Goffman, E.: Behavior in Public Places: Notes on the Social Organization of Gatherings, Simon \& Schuster (1966)

[Gosztolya 15] Gosztolya, G.: On evaluation metrics for social signal detection, in Proceedings of Interspeech, pp. 2504-2508 (2015)

[Higashinaka 14] Higashinaka, R., Imamura, K., Meguro, T., Miyazaki, C., Kobayashi, N., Sugiyama, H., Hirano, T., Makino, T., and Matsuo, Y.: Towards an open-domain conversational system fully based on natural language processing, in Proceedings of the International Conference on Computational Linguistics (COLING), pp. 928-939 (2014)

[Hinton 02] Hinton, G. E.: Training products of experts by minimizing contrastive divergence, Neural Computation, Vol. 14, No. 8, pp. 1771-1800 (2002)

[Huang 16] Huang, Y., Gilmartin, E., and Campbell, N.: Engagement recognition using auditory and visual cues, in Proceedings of Interspeech (2016)

[Inoue 15] Inoue, K., Wakabayashi, Y., Yoshimoto, H., Takanashi, K., and Kawahara, T.: Enhanced speaker diarization with detection of backchannels using eye-gaze information in poster conversations, in Proceedings of Interspeech, pp. 3086-3090 (2015)

[Inoue 16a] Inoue, K., Lala, D., Nakamura, S., Takanashi, K., and Kawahara, T.: Annotation and analysis of listener's engagement based on multi-modal behaviors, in Proceedings of the International Workshop on Multimodal Analyses Enabling Artificial Agents in Human-Machine Interaction (MA3HMI) (2016)

[Inoue 16b] Inoue, K., Milhorat, P., Lala, D., Zhao, T., and Kawahara, T.: Talking with ERICA, an autonomous android, in Proceedings of the Annual SIGdial Meeting on Discourse and Dialogue (SIGDIAL), pp. 212-215 (2016)

[Ishi 12] Ishi, C. T., Ishiguro, H., and Hagita, N.: Evaluation of formant-based lip motion generation in tele-operated humanoid robots, in Proceeding of the IEEE/RSJ International Conference on Intelligent Robots and Systems (IROS), pp. 2377-2382 (2012)

[石井 11] 石井 亮, 大古 亮太, 中野, 有紀子, 西田 豊明: 視線と頭 部動作に基づくユーザの会話参加態度の推定, 情報処理学会論文 誌, Vol. 52, No. 12, pp. 3625-3636 (2011)

[Kaushik 15] Kaushik, L., Sangwan, A., and Hansen, J. H. L.: Laughter and filler detection in naturalistic audio, in Proceedings of Interspeech, pp. 2509-2513 (2015)

[河原 13] 河原 達也 : 音声対話システムの進化と淘汰 一歴史と最 近の技術動向－, 人工知能学会誌, Vol. 28, No. 1, pp. 45-51 (2013)

[Kumano 13] Kumano, S., Otsuka, K., Matsuda, M., Ishii, R., and Yamato, J.: Using a probabilistic topic model to link observers' perception tendency to personality, in Proceedings of the International Conference on Affective Computing and Intelligent Interaction (ACII), pp. 588-593 (2013)

[熊野 17] 熊野史朗, 石井亮, 大塚和弘: 評定者個人に特化した他 者感情理解モデル, 2017 年度人工知能学会全国大会 (第 31 回), 2H4-OS-35b-3in2 (2017)

[Kuno 07] Kuno, Y., Sadazuka, K., Kawashima, M., Yamazaki, K., Yamazaki, A., and Kuzuoka, H.: Museum guide robot based on sociological interaction analysis, in Proceedings of the ACM Conference on Human Factors in Computing Systems (CHI), pp. 1191-1194 (2007)

[Langton 00] Langton, S. R. H., Watt, R., and Bruce, V.: Do the eyes have it? Cues to the direction of social attention, Trends in Cognitive
Sciences, Vol. 4, No. 2, pp. 50-59 (2000)

[Michalowski 06] Michalowski, M. P., Sabanovic, S., and Simmons, R.: A spatial model of engagement for a social robot, in Proceedings of the International Workshop on Advanced Motion Control (AMC), pp. 762-767 (2006)

[Morency 06] Morency, L. P., Christoudias, C. M., and Darrell, T.: Recognizing gaze aversion gestures in embodied conversational discourse, in Proceedings of the ACM International Conference on Multimodal Interfaces (ICMI), pp. 287-294 (2006)

[Morency 07] Morency, L. P., Quattoni, A., and Darrell, T.: Latentdynamic discriminative models for continuous gesture recognition, in Proceedings of the IEEE Conference on Computer Vision and Pattern Recognition (CVPR) (2007)

[Nakano 10] Nakano, Y. I. and Ishii, R.: Estimating user's engagement from eye-gaze behaviors in human-agent conversations, in Proceedings of the ACM Conference on Intelligent User Interfaces (IUI), pp. 139-148 (2010)

[Ozkan 10] Ozkan, D., Sagae, K., and Morency, L. P.: Latent mixture of discriminative experts for multimodal prediction modeling, in Proceedings of the International Conference on Computational Linguistics (COLING), pp. 860-868 (2010)

[Ozkan 11] Ozkan, D. and Morency, L. P.: Modeling wisdom of crowds using latent mixture of discriminative experts, in Proceedings of the Annual Meeting of the Association for Computational Linguistics (ACL), pp. 335-340 (2011)

[Peters 05] Peters, C.: Direction of attention perception for conversation initiation in virtual environments, in Proceedings of the International Workshop on Intelligent Virtual Agents (IVA), pp. 215-228 (2005)

[Poggi 07] Poggi, I.: Mind, Hands, Face and Body: A Goal and Belief View of Multimodal Communication, Weidler (2007)

[境 16] 境くりま, 石井 カルロス寿憲, 港 隆史, 石黒 浩 : 音声に対 応する頭部動作のオンライン生成システムと遠隔操作における効 果, 電子情報通信学会論文誌, Vol. J99-A, No. 1, pp. 14-24 (2016)

[Sidner 02] Sidner, C. L. and Dzikovska, M.: Human-robot interaction: Engagement between humans and robots for hosting activities, in Proceedings of the ACM International Conference on Multimodal Interfaces (ICMI), p. 123 (2002)

[Sidner 05] Sidner, C. L., Lee, C., Kidd, C. D., Lesh, N., and Rich, C.: Explorations in engagement for humans and robots, Artificial Intelligence, Vol. 166, No. 1-2, pp. 140-164 (2005)

[Skantze 15] Skantze, G. and Johansson, M.: Modelling situated human-robot interaction using IrisTK, in Proceedings of the Annual SIGdial Meeting on Discourse and Dialogue (SIGDIAL), pp. 165167 (2015)

[高梨 09] 高梨 克也, 榎本 美香:「特集-聞き手行動から見たコミュ ニケーション」編集にあたって, 認知科学, Vol. 16, No. 1, pp. 5-11 (2009)

[和田 96] 和田さゆり：性格特性用語を用いた Big Five 尺度の作 成, 心理学研究, Vol. 67, No. 1, pp. 61-67 (1996)

[Wilcock 15] Wilcock, G. and Jokinen, K.: Multilingual WikiTalk: Wikipedia-based talking robots that switch languages, in Proceedings of the Annual SIGdial Meeting on Discourse and Dialogue (SIGDIAL), pp. 162-164 (2015)

[Xu 13] Xu, Q., Li, L., and Wang, G.: Designing engagement-aware agents for multiparty conversations, in Proceedings of the ACM Conference on Human Factors in Computing Systems (CHI), pp. 2233 2242 (2013)

[Yu 04] Yu, C., Aoki, P. M., and Woodruff, A.: Detecting user engagement in everyday conversations, in Proceedings of the International Conference on Spoken Language Processing (ICSLP), pp. 1329-1332 (2004)

[Yu 16] Yu, Z., Nicolich-Henkin, L., Black, A. W., and Rudnicky, A. I.: A Wizard-of-Oz study on a non-task-oriented dialog systems that reacts to user engagement, in Proceedings of the Annual SIGdial Meeting on Discourse and Dialogue (SIGDIAL), pp. 55-63 (2016)

〔担当委員 : 石井 亮〕

2017 年 9 月 1 日 受理 


\section{著 者 紹 介}

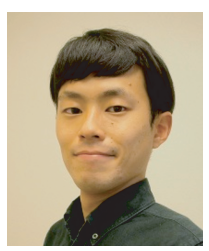

\section{井上 昂治(学生会員)}

2015 年 京都大学大学院情報学研究科修士課程修了. 現在, 同大学院博士後期課程在学中，および日本学術振興会特別 研究員 (DC1). 音声言語処理, マルチモーダルインタラク ションに関する研究に従事. 情報処理学会, 日本音響学会, 電子情報通信学会, IEEE，ISCA 各会員.

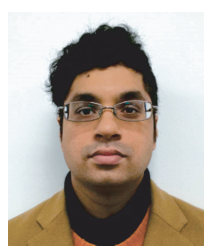

\section{Divesh Lala}

2015 年 京都大学大学院情報学研究科博士後期課程修了。 博士 (情報学). 同年, 日本学術振興会外国人特別研究員. 現在, 京都大学大学院情報学研究科研究員. マルチモーダ ルインタラクションに関する研究に従事。

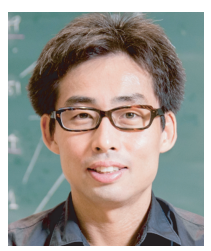

\section{吉井 和佳}

2008 年 京都大学大学院情報学研究科博士後期課程修了. 博士 (情報学). 同年，産業技術総合研究所情報技術研究部 門に入所. 2014 年 京都大学大学院情報学研究科講師に着 任. 音楽情報処理, 統計的音響信号処理の研究に従事.

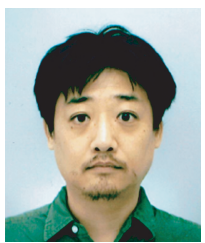

高梨 克也(正会員)

2000 年 京都大学大学院人間 - 環境学研究科博士課程単位 取得退学. 博士 (情報学). 独立行政法人情報通信研究機構 専攻研究員, 京都大学学術情報メディアセンター特定助教, 科学技術振興機構さきがけ専従研究者などを経て, 現在, 京都大学大学院情報学研究科研究員. コミュニケーション の組織化を支える認知的・社会的プロセスの解明に従事。 言語処理学会, 日本認知科学会, 社会言語科学会, 組織学 会 各会員. 一般社団法人社会対話技術研究所理事.

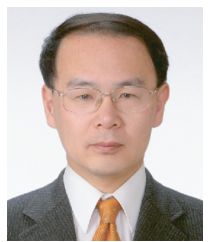

河原 達也(正会員)

1987 年 京都大学工学部情報工学科卒業. 1989 年 同大学 院修士課程修了. 1990 年 京都大学工学部助手. 1995 年 同助教授. 2003 年 同大学学術情報メディアセンター／情 報学研究科教授. 現在に至る. この間, 1995 96 年米国. ベル研究所客員研究員. 1998 2006 年 A T R 客員研究員. 2006 年〜 情報通信研究機構短時間研究員・招へい専門員. 音声情報処理，特に音声認識および対話システムに関する 研究に従事. 博士 (工学). 科学技術分野の文部科学大臣表 暗 (2012 年度), 日本音響学会加粟屋潔学術奨励賞 (1997 年度), 情報処理学 会から坂井記念特別賞 (2000 年度), 喜安記念業績賞 (2011 年度), 論文賞 (2012 年度) を受賞. IEEE ASRU 2007 General Chair, INTERSPEECH 2010 Tutorial Chair，IEEE ICASSP 2012 Local Arrangement Chair，言語処理学会理事，情報 処理学会音声言語情報処理研究会主査, 情報処理学会理事, APSIPA 理事, ISCA 理事を歴任. IEEE Fellow. 情報処理学会, 日本音響学会, 電子情報通信学会, 言 語処理学会, ISCA, APSIPA 各会員. 日本学術会議連携会員. 